\title{
The future of Swiss hydropower: how to distribute the risk and the profits?
}

\author{
Mirjam Kosch ${ }^{1,3}$, Regina Betz ${ }^{1}$, Thomas Geissmann ${ }^{1}$, Moritz Schillinger ${ }^{2}$ and Hannes Weigt $2^{*}$ (1)
}

\begin{abstract}
Low electricity prices put economic pressure on hydropower companies. A more flexible water fee design can counteract this pressure and support hydropower companies during times when market revenues are low. However, this comes at the cost of lower revenues for resource owners. Using a sample of cost data for 62 companies and revenue data derived from an electricity market model, we have quantified this trade-off for the case of Switzerland. We found that electricity market price developments dominate changes in water fees and that for the profitability of hydropower, electricity prices are more important than water fee levels. However, with electricity prices of around CHF 40 per MWh, water fees can make the difference between profit and loss. Therefore, while flexible water fee regimes shift the market risk from producers to resource owners to some extent, the extent of this risk shift depends on the detailed design of the flexible regime.
\end{abstract}

Keywords: Hydropower, Water fees, Natural resource rents, Distributional impact

\section{Introduction}

The exploitation of natural resources such as hydropower generates resource rents, which can be defined as the difference between the revenue from selling a natural resource and the cost of extracting it. These rents can be allocated to the resource owner (usually the public sector) in the form of a tax on the rent, for instance, or they are absorbed by the resource user (state- or privately owned electricity companies). In the case of hydropower, the resource rent is the value of the electricity produced minus the cost of its generation (including capital investment, labor, and taxes).

Worldwide, many countries that are rich in hydropower levy royalties or fees on the use of their hydro resources (see, e.g., Pineau et al., 2017; Glachant et al., 2015). Mostly, these fees are determined and fixed by political institutions. They do not-or only to a limited extent-reflect heterogeneous cost structures and changing revenue options for hydro producers. For resource

\footnotetext{
*Correspondence: hannes.weigt@unibas.ch

${ }^{2}$ Forschungsstelle für Nachhaltige Energie- und Wasserversorgung

(FoNEW), University of Basel, Peter Merian-Weg 6, 4002 Basel, Switzerland Full list of author information is available at the end of the article
}

owners, this has the advantage of stable income streams. Consequently, all the market risk lies with the producers, who pay the same fee irrespective of their economic circumstances.

Such fee structures do not adequately reflect the economic value of the resource, but most owe their existence to historical, political, or practical reasons. Glachant et al. (2015) provide an overview of hydropower regimes in 14 European countries (including Switzerland), comparing concession regimes, obligations, and support schemes. An overview comparing China, Brazil, Canada, and the United States-the four leading hydropower producers globally-has concluded that royalties are generally determined in an "arbitrary and unsystematic manner" (Pineau et al., 2017). One exception is Norway, where the government has implemented a tax of $37 \%$ on the resource rent of hydropower (OECD, 2019). ${ }^{1}$

Taking the case of Switzerland, where hydropower plants generate around $60 \%$ of the electricity consumed, this paper assesses the impact of changing from a fixed

\footnotetext{
${ }^{1}$ The Swiss canton of the Grisons also levied a tax on the resource rent of hydropower, but it was abandoned in 2006 (Canton of Grisons Chancellery, 2005).
} original author(s) and the source, provide a link to the Creative Commons licence, and indicate if changes were made. The images or other third party material in this article are included in the article's Creative Commons licence, unless indicated otherwise in a credit line to the material. If material is not included in the article's Creative Commons licence and your intended use is not permitted by statutory regulation or exceeds the permitted use, you will need to obtain permission directly from the copyright holder. To view a copy of this licence, visit http://creativecommons.org/licenses/by/4.0/. 
water fee regime to a more market-based solution. By considering revenue options and the costs related to the production of hydropower, we quantify the impact from two perspectives: (1) the rents of electricity producers and (2) the revenues of resource owners. Finally, we address the question of whether and how a water fee design impacts the parties in question.

Currently, Switzerland has a fixed water fee, which is paid by the owners of hydropower plants to the cantons and municipalities owning the water resource rights. The Swiss government has set the maximum water fee level at CHF 110 per kW gross capacity (Art. 49 I, Swiss Water Rights Act (WRG)), based not on economic but rather on physical factors. In the past, the maximum water fee level was increased several times without strong opposition as the revenues of hydropower companies have been traditionally high due to high electricity prices and non-liberalized markets (i.e., captive end-consumers). However, due to partial market liberalization and lower international electricity prices, revenues have dropped, leading to cost pressures on hydropower companies. Consequently, Swiss hydropower producers have been calling for a change to a more flexible water fee regime, which would shift part of the market risk from electricity producers to the owners of the resource-in this case, cantons and municipalities-and reduce the cost pressure on companies. However, since for some cantons and municipalities, the revenue from water fees constitute a considerable share of their total budget, the prospect of lower incomes has led the cantons and municipalities to oppose a more flexible design (Frauendorfer \& Schürle, 2017).

Focusing on the year 2025, by which time the Swiss government intends to implement a new water fee regime, we evaluated different water fee reform options: (a) the current fixed water fee, (b) a flexible water fee dependent on a reference market price and, therefore, reflecting revenue options of power plants, and (c) a tax on the resource rent, reflecting costs and revenues for each power plant. Specifically, we asked the following questions: "What is the impact of different regimes on the profitability of hydropower producers?" and "How does a change in regime affect the revenues of resource owners (cantons and municipalities)?" As the answers to these questions depend heavily on market outcomes, we distinguished four different developments, ranging from optimistic to pessimistic, concerning the electricity price. Consequently, and in conclusion, we asked ourselves "How do the water fee regimes affect the distribution of market risk between resource users and resource owners?".

Of course, a more sophisticated regime comes at the expense of a greater administrative burden, and-in the case of a tax on resource rents-higher transparency requirements are needed for the companies involved. Analysis of the impact of the different regimes might also provide information on whether a more elaborate regime is justified.

For our analysis, we combined a sample of cost data for 62 companies ("Partnerwerke") with revenue data derived from the Swissmod electricity market model (Schlecht \& Weigt, 2014) based on the WASTA ("Statistik der Wasserkraftanlagen") database (Swiss Federal Office of Energy, SFOE, 2016, 2017). We matched cost and revenue data to calculate the net profits of hydropower under different water fee regimes. The design of the regimes we analyzed is based on existing policies and assumptions about future policy design.

The following four main insights emerge from our analysis: First, electricity market price developments dominate water fee changes. In other words, electricity prices are more important than water fee levels for the profitability of hydropower. Second, with electricity prices of around CHF 40 per MWh, water fees can make the difference between profit and loss. Third, there is a larger variability between power plants than between scenarios. For every scenario, we find plants that would be making a profit and others that would be making a loss. On the other hand, a tax on resource rents decreases this difference between companies, leading to more equally distributed profits across companies. Fourth, water fee regimes that consider electricity market price developments can result in up to $80 \%$ higher revenues for resource owners in a good year. By contrast, in years with very low electricity prices, resource owners would receive up to $70 \%$ less revenue in the case of a flexible regime and might receive nothing at all in the case of a tax on the resource rent. In summary, while flexible water fee regimes can shift the market risk from producers to resource owners to some extent, the extent of this risk shift depends on the details of how the flexible regime is designed.

The idea of a market-based water fee system is not new for Switzerland. Before the introduction of (partial) market liberalization, Banfi et al. (2005) claimed that a more flexible system was needed to take into account the different production costs of plants as well as the variation in electricity prices over time. Banfi and Filippini (2010) proposed the introduction of a water fee system based on a resource rent tax and estimated the impact on utilities and their competitiveness as well as the financial implications for the resource owners, the cantons and municipalities. These two early contributions provide a solid foundation for the discussion in this study, especially through their detailed review of the necessity of a flexible water fee system and a resource rent tax, in particular.

Later studies have focused mainly on production cost data (see Filippini \& Geissmann, 2014, 2018). For our 
own study, we extend the approach of modelling the financial implications of a shift to include a resource rent tax system, using recent cost data and a detailed bottomup electricity market model to reflect the revenue side in different scenarios. We further broaden the quantitative analysis by modelling a flexible water fee system that depends on a reference market price.

The contribution of this paper is, therefore, twofold. First, we create a unique data set, combining updated cost and modeled revenue data from power plants to derive their resource rents. Second, we analyze the effects of different assumptions on international market developments and nationally determined water fee regimes through a detailed bottom-up electricity market model. This approach allows us to assess the impact of changing water fee regimes on both the profitability of companies and the revenues of resource owners.

The remainder of this paper is organized as follows: The following section explains the situation for hydropower generation in 2015/16, as well as data construction and the electricity market model used for revenue calculation. Section 3 introduces the scenario design for future market conditions and water fee regimes, while Sect. 4 discusses the impact on companies and resource owners, respectively, as well as the findings for different reference market prices. Section 5 closes with a discussion and conclusions.

\section{A first look at the data: the Swiss hydropower situation}

The aim of this section is twofold. First, we provide some policy context on water fees in Switzerland and present the economic situation for Swiss hydropower in 2015/16 based on cost and revenues. Second, we describe the data sources and construction.

\subsection{Water fees: past, present, and future}

Currently, Switzerland has a fixed water fee paid by the owners of hydropower plants to the owners of the water resource rights. According to federal legislation (Art. 76 IV of the Swiss Federal Constitution and Art. 2 I of the Swiss Water Rights Act (WRG)), this right lies with the cantons $^{2}$ and can be transferred to other parties, such as municipalities, districts, and cooperatives, either in part or its entirety. The Swiss government has the right to determine the maximum water fee level (Art. 49 I WRG).

${ }^{2}$ Besides the earnings from water fees, cantons with hydropower plants receive the proceeds from taxes on income and property. Much of this tax revenue flows to cantons, with a smaller share going to municipalities. In addition, the cantons may receive dividends when holding the shares of the hydropower utilities and profit taxes. Some of the latter may also generate revenue for the Swiss government.
The water fee is based on the gross capacity of a plant and is estimated using the gradient and the amount of water that can be used for electricity generation, depending on the hydrological conditions as defined in the concession. Consequently, it is not based on economic factors but on physical principles. Hence, in contrast to a tax on the resource rent, it takes no account of changing market conditions or different production costs across power plants.

The water fee level has been adjusted several times since its introduction in 1918 when it started at a level of CHF 6 per horsepower (around CHF 8.16 per kW). The last increase occurred in two increments from $80 \mathrm{CHF} /$ $\mathrm{kW}$ to $100 \mathrm{CHF} / \mathrm{kW}$ in January 2011 and $110 \mathrm{CHF} / \mathrm{kW}$ in January 2015. Launched in 2008 by a parliamentary initiative, the last increase was justified by higher peaks and balancing electricity prices, the higher value of energy storage, and adjustment for inflation (Swiss Federal Council, 2018).

However, soon after increasing the water fee maximum, the situation changed: Electricity wholesale market prices and thus hydropower plant profits fell. The economic crisis, the low price of coal and $\mathrm{CO}_{2}$ certificates, and subsidies for renewable energies in European countries all led to a significant drop in overall electricity wholesale market prices and reduced the spread between peak and offpeak prices. Peak prices dropped from $152 \mathrm{CHF} / \mathrm{MWh}$ in 2008 to $44.79 \mathrm{CHF} / \mathrm{MWh}$ in 2016, and the spread from 34 CHF/MWh to 3.5 CHF/MWh (Swiss Federal Council, 2018). These developments significantly decreased the revenue options and thus the profitability of hydropower, particularly for storage and pumped storage plants.

Figure 1 shows the production costs and revenues of two different types of hydropower plants in 2015/16. On average, costs including water fees are higher than revenues. ${ }^{3}$ Hydropower plants, especially (pumped) storage plants, suffered from net losses, whereas-on averagethey would have been profitable without water fees.

This critical situation for companies has been exacerbated by the partial liberalization of the electricity market, which no longer allows producers to sell (all) their electricity to captive customers at generation cost, but obliges them to sell at market prices. ${ }^{4}$ These market and regulatory developments, together with the legal requirement to review water fee levels by 2024 , have led to the recent discussion about reforming the water fee regime.

\footnotetext{
3 The average water fees were estimated based on the actual water fee payments of companies in our sample.

${ }^{4}$ In Switzerland, large electricity consumers have been able choose their suppliers since 2009 (partial liberalization). It is likely that in the near future, small consumers (households) will also be able choose their suppliers (complete liberalization).
} 


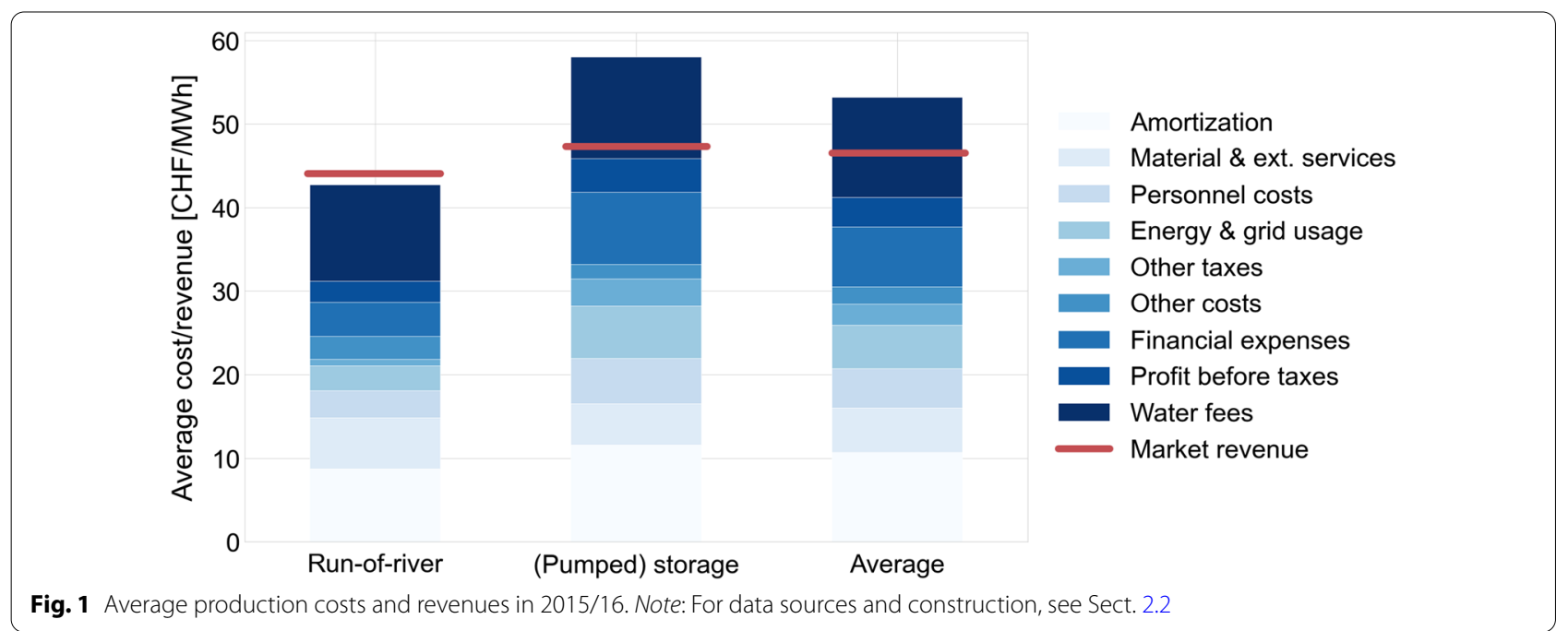

Currently, the most likely policy change is for flexible water fees which depend on electricity prices and, therefore, reflect revenue options for hydropower, causing higher when market revenues are high and vice versa. ${ }^{5}$ However, a flexible regime would not reflect the heterogeneity in the cost structures of individual power plants, although this could be achieved by placing a tax on the resource rent, which would take individual costs and revenues into consideration. In this paper, all three options are analyzed: a fixed fee, a flexible fee, and a tax on the resource rent. ${ }^{6}$

\subsection{Production cost}

Figure 1 shows the average production cost for all companies in our sample. ${ }^{7}$ The average cost (using a financial cost accounting approach ${ }^{8}$ ) is about 53.2 CHF/MWh, of which $12.0 \mathrm{CHF} / \mathrm{MWh}$ or $23 \%$ is due to water fee payments. This implies that the average cost net of water fees is $41.2 \mathrm{CHF} / \mathrm{MWh}$.

\footnotetext{
${ }^{5}$ Following the Swiss Federal Council, six variations are to be assessed (Swiss Federal Council, 2018): (i) a flexible water fee (with a fixed and a variable part); (ii) a tax on the resource rent; (iii) no federal maximum water fee level but qualitative guidance; (iv) cantonal regulation only, no maximum imposed at a federal level; (v) a levy on consumers, for example, via a network surcharge (instead of concession holders); and (vi) integration into the national fiscal equalization scheme.

${ }^{6}$ In Betz et al. (2019), we also looked at the impact of different designs of (partly) flexible water fee approaches. These are more closely related to the political debate in Switzerland, but they do not add any additional insights to the general discussion.

7 Disaggregated data are available on request.

8 The calculation of the production cost of hydropower companies can be estimated from a financial or imputed cost perspective. For our analysis, we use a financial cost perspective. Information on the imputed costs perspective is provided by Filippini and Geissmann (2018).
}

Figure 1 further distinguishes between run-of-river and (pumped) storage. The cost structure of the company types varies significantly. The costs of companies classified as (pumped) storage tend to be higher (58.0 $\mathrm{CHF} / \mathrm{MWh})$ compared with run-of-river plants $(42.7$ $\mathrm{CHF} / \mathrm{MWh}$ ). The following three reasons explain this difference:

First, pumped storage plants are more capital-intensive than run-of-river plants because of their technological complexity. Also, they tend to be built in geographically remote areas with complicated Alpine topography, while run-of-river plants primarily built in flat and easily reachable areas in the densely populated midlands of Switzerland. Second, they incur higher operating costs due to the electricity required to pump water when prices are low. Third, in recent years, several large construction projects have been undertaken in Switzerland to expand the pumped storage capacity, which has led to an increase in capital costs.

Besides these mainly exogenous factors, cost might also differ due to endogenous cost drivers such as the efficiency of operational processes. Based on Banfi and Filippini (2010) and Filippini et al. (2018), who did, however, not point towards systematic patterns in cost efficiency differences across plant types, we assume that such inefficiencies are randomly and uniformly distributed across plants and plant types. The share of the water fee of the total production costs is $27 \%$ (11.6 CHF/MWh) for runof-river and 21\% (12.2 CHF/MWh) for (pumped) storage. This implies that the cost net of water fees is $31.2 \mathrm{CHF} /$ MWh for run-of-river and 45.9 CHF/MWh for (pumped) storage. 


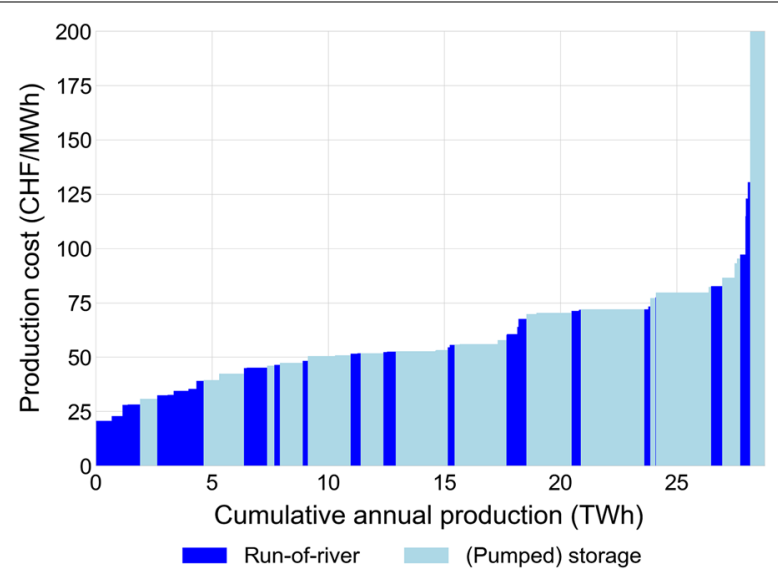

Fig. 2 Pseudo-merit-order curve for 2015/16. Note: In contrast to a "real" merit-order curve, the pseudo-merit-order curve shows not marginal but average production cost. On the $x$-axis, we see cumulative annual production instead of installed capacities. For data sources and construction, see Sect. 2.2

Figure 2 shows the individual production costs of each plant in our sample in a pseudo-merit-order curve ${ }^{9}$ and confirms the substantial cost differences between plants. Generally, the production costs of (pumped) storage plants are higher, but they can also shift their production to times with higher prices and generate higher revenues (see following section).

We derived production costs for a panel data set of 62 hydropower companies for 2015/16. Most of these companies are so-called "Partnerwerke," which means that different utilities jointly hold the concession for a power plant. Based on annual reports, income statements, and balance sheets, financial information is gathered and combined with the amount of electricity generated, the pump energy consumed, and the accumulated installed generator power, as provided by the Swiss Federal Office of Energy in WASTA, the statistics for hydropower plants in Switzerland (SFOE, 2016, 2017).

According to Filippini and Geissmann (2014, 2018), hydropower companies can be classified into four distinctive technical categories reflecting the predominant technology of the stations operated by a company. However, for the purpose of this study, we distinguish only between the two categories run-of-river and (pumped) storage $^{10}$ resulting in the following numbers covered by

\footnotetext{
${ }^{9}$ In contrast to a "real" merit-order curve, the pseudo-merit-order curve shows not only marginal but also average production cost.

10 A company is categorized as run-of-river if more than $50 \%$ of the expected annual generation stems from run-of-river stations. Analogously, a company is of the (pumped) storage type if more than $50 \%$ of the expected electricity generation is generated by storage units.
}

our sample: 36 run-of-river companies and 28 (pumped) storage companies. This sample represents around 63\% of modeled hydro generation in Swissmod, although only around 25\% of the hydropower plants listed in WASTA. Looking at individual plant types, it represents around $86 \%$ of the total expected storage production, $76 \%$ of the expected pumped storage production (79\% of the total combined (pumped) storage generation), and around $44 \%$ of the expected run-of-river production in 2016.

\subsection{Revenue from the electricity market}

In Fig. 1, a red bar shows the average revenues of hydro production in 2015 and 2016. These amounted to 46.5 CHF/MWh. ${ }^{11}$ These revenues differ between the two plant types. Storage and pumped storage yield a much higher revenue of $47.4 \mathrm{CHF} / \mathrm{MWh}$ owing to their ability to generate electricity during peak price periods. In comparison, run-of-river plants, which usually operate nonstop to provide baseload, have a revenue of $44.1 \mathrm{CHF} /$ MWh. However, due to a reduction in peak prices and price spreads in recent years, storage technologies have also experienced economic pressure.

For the market revenue ${ }^{12}$ estimates, we rely on simulations from Swissmod, a Swiss and Central European electricity market model (Abrell et al., 2019; Schlecht \& Weigt, 2014). Swissmod is a traditional cost minimizing or welfare-maximizing dispatch model based on a DC load flow approach (a model description is provided in "Appendix A"). It shows Switzerland in a detailed spatial resolution of approximately 230 nodes and 400 transmission lines with the surrounding countries Austria, Germany, France, and Italy aggregated. Besides the detailed network representation, Swiss hydropower is represented in detail, with approximately 400 hydropower stations, which is $96 \%$ of Swiss hydropower production. Hydropower revenues are derived from the simulated hydropower dispatch (generation and pumping) and the resulting market prices. While Swissmod reproduces the dynamics of the day-ahead spot market, the market revenues do not include additional revenue options from future, intra-day, or system service markets.

\subsection{Resource rents: matching costs and revenues}

Rents-or net profits-from hydropower are defined as revenues net of production costs. Therefore, to calculate

\footnotetext{
11 The simulated day-ahead market price was 43.6 CHF/MWh in 2015.

12 Currently, the electricity market in Switzerland is only partially liberalized, and revenues consist of two parts: revenues from selling electricity on the free market, and revenues from sales to captive customers. However, as we expect full market liberalization to commence by 2025 , we only use market revenues for the purpose of our analysis. Introducing revenues from captive customers does not change the general results but relaxes the situation for companies with a large share of captive customers to some extent.
} 
Table 1 Fuel and carbon price scenarios

\begin{tabular}{ll}
\hline Scenario & Fuel and carbon price development \\
\hline Base & Fuel and carbon prices as in 2015 \\
EU & Fuel and carbon prices as in the EU Reference Scenario (European Commission, 2016) \\
$C++F++$ & Fast linear increase in carbon price (50€/t in 2030) and fuel prices (+ 100\% until 2030) \\
$C-F-$ & Linear decrease in carbon price (4€/t in 2030) and fuel prices (-50\% until 2030) \\
\hline
\end{tabular}

the profitability of hydropower companies, we need to match the revenue data, calculated at a plant level, with the cost data, which are only available at a company ("Partnerwerk") level. Using publicly available data on the plants of a company, we manually match the two data sets. During this process we omit some information on the revenue side, as our company sample includes only around $63 \%$ of total hydropower production. In comparison, the revenue side can be calculated for $96 \%$ of total production.

\section{Scenario design: water fee design options under various electricity market developments}

Having presented the situation in 2015/16, we now turn to future developments. For four different electricity price developments for the year 2025, we analyze the impact of three different water fee design options.

\subsection{Possible market developments for fuel and carbon prices}

When water fees are flexibly designed, they depend on market developments. To analyze a broad range of possible developments, we use four different fuel and carbon price scenarios (see Table 1). Under the Base scenario, we assume that fuel and carbon prices stay constant at their 2015 levels. In the other three scenarios, we additionally alter fuel and carbon prices, as described in the table below.

The scenarios capture a range of possible market developments and are not a forecast of the most likely developments. The underlying demand and power plant portfolios develop according to the Swiss energy perspectives 2050 (Prognos, 2012) for Switzerland and the EU Reference Scenario (European Commission, 2016) for the neighboring countries. The four price scenarios are based on real 2015 values, in other words, without inflation or changes in the exchange rate. ${ }^{13}$ They indicate market income potentials for companies but do not capture all market and trading possibilities such as future and

\footnotetext{
${ }^{13}$ For the conversion from EUR to CHF, we use an exchange rate of 1.0679 $\mathrm{CHF} / €$ in 2015 and $1.0902 \mathrm{CHF} / €$ in 2016 (based on www.ecb.europa.eu/ stats).
}

intra-day trading, system services, or special end-user tariffs for green/local production.

Table 2 shows the average spot market prices and unit revenues of run-of-river and (pumped) storage plants for 2025. The results highlight the broad range of possible future price levels and their dependency on European fuel and carbon prices. We observe average spot market prices from $31 \mathrm{CHF} / \mathrm{MWh}$ for the scenario with decreasing fuel and carbon prices to $95 \mathrm{CHF} / \mathrm{MWh}$ for the scenario with increasing fuel and carbon prices. Unit revenues are higher for (pumped) storage than for runof-river plants. Nevertheless, the fact that differences are not very pronounced between technologies shows that the spread between base and peak prices is still expected to be relatively low in 2025 .

\subsection{Three water fee regimes}

We analyze three different water fee (WF) regimes: fixed fee, flexible fee, and tax on resource rent. In the latter two regimes, the average water fee revenues are equal across all three water fee regimes. In other words, in the flexible regimes, the water fee level depends on the development of fuel and carbon prices, but the expected value (average over all four fuel and carbon price realizations) is constant across regimes. The regimes are summarized in Table 3 and described below.

FIXED WATER FEE-The fixed water fee regime represents the current situation. Water fees are fixed at $\mathrm{CHF}$ 110 per $\mathrm{kW}$ of gross capacity $\left(\mathrm{kW}_{\mathrm{Br}}\right)$ :

Table 2 Average spot market price and unit revenues in 2025 (CHF/MWh)

\begin{tabular}{lcllc}
\hline \multirow{4}{*}{ Spot } & \multicolumn{3}{l}{ Unit revenue } \\
\cline { 3 - 5 } \cline { 3 - 5 } & & Uniform & \multicolumn{2}{l}{ Differentiated } \\
\cline { 3 - 5 } & & & Run-of-river & $\begin{array}{c}\text { (Pumped) } \\
\text { storage }\end{array}$ \\
\hline C-F- & 30.6 & 32.0 & 30.2 & 37.9 \\
Base & 42.2 & 44.2 & 41.0 & 55.0 \\
EU & 77.3 & 80.3 & 77.3 & 90.2 \\
$C++F++$ & 94.9 & 98.8 & 94.6 & 112.8 \\
\hline
\end{tabular}


Table 3 Water fee regimes

\begin{tabular}{lll}
\hline Regime & Water fee (WF) & \\
\hline Fixed & Current water fee level based on gross capacity & WF $=110 \mathrm{CHF} / \mathrm{kW}_{\mathrm{Br}}$ \\
Flexible & Flexible fee depending on reference market price (RMP) & $\mathrm{WF}^{\mathrm{a}}=1.75 \mathrm{RMP} / \mathrm{kW} \mathrm{Br}$ \\
Tax on resource rent & Tax of 38.7\% on resource rent & $\mathrm{WF}=0.387(\mathrm{R}-\mathrm{C})$ \\
\hline
\end{tabular}

Based on Swiss Federal Council (2017) and SFOE $(2018 \mathrm{a}, \mathrm{b}) . \mathrm{kW}_{\mathrm{Br}}$ stands for $\mathrm{kW}$ of gross capacity

${ }^{a}$ The maximum water fee level allowed by federal regulation is set at $110 \mathrm{CHF} / \mathrm{kW}_{\mathrm{Br}}$ Only the cantons of Bern, Jura, Zug, and Vaud stayed below this tax level (Swiss Federal Council, 2018). For our analysis, we use the observed water fee payments in 2015/16. As the flexible water fee payments are calculated in relation to observed payments, we assume that these cantons continue to have a relatively lower tax level

$$
\mathrm{WF}=110 \mathrm{CHF} / \mathrm{kW} \mathrm{Br}_{\mathrm{Br}}
$$

For cantons and municipalities of Switzerland, this implies a constant revenue stream independent of the market situation; resource owners do not bear any market risk. For the companies, however, a fixed water fee implies an ongoing cost, so they bear the entire market risk.

FLEXIBLE WATER FEE-The main principle of flexible water fee regimes is that the water fee level depends on a reference market price (RMP), reflecting the revenue possibilities of hydropower. How this reference market price is defined needs to be determined, however. For our analysis, we use the average unit revenue (CHF per MWh) of an average power plant as the RMP. Clearly, this is highly dependent on the wholesale electricity market price. Also, water fees can be either wholly flexible or consist of a fixed part (minimum fee) and a flexible part. For our analysis, we assume a completely flexible water fee:

$$
\mathrm{WF}=\alpha \mathrm{RMP} / \mathrm{kW}_{\mathrm{Br}}
$$

In principle, water fee payments depend on the revenue options of companies. If a hydropower plant can generate large revenues, their water fee payments are correspondingly high-and the reverse also applies. Consequently, some market risk shifts to the resource owners, whose revenues are no longer constant but depend on market outcomes. Nevertheless, production costs are not reflected in this calculation.

We need to determine a slope parameter $\alpha$, where the expected water fee revenues are kept constant at the current level. For the given set of fuel and carbon price developments, we find that $\alpha=1.75$ (see Fig. 3). ${ }^{14}$

TAX ON RESOURCE RENT-The third water fee regime is a tax on the resource rent of each plant $i$. We

\footnotetext{
${ }^{14}$ We manually determine the slope parameter $\alpha$ such that the expected total water fee revenues across all plants reach the current level of water fee payments.
}

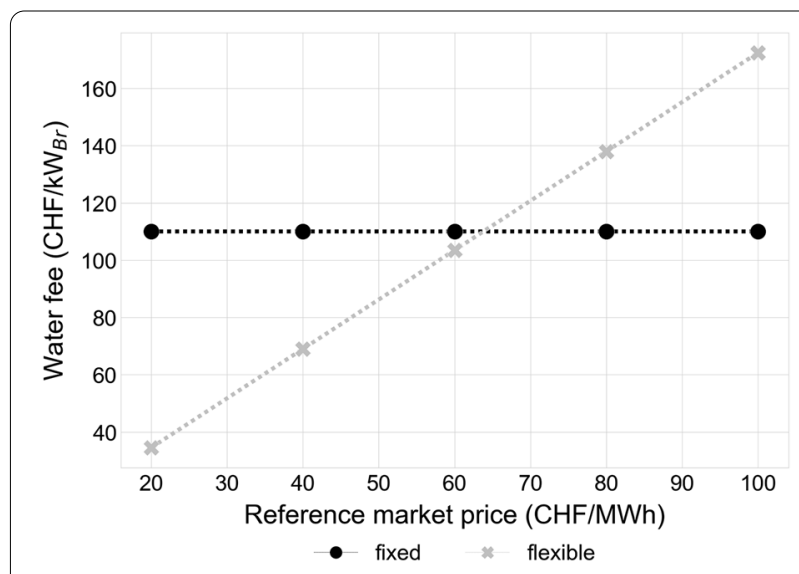

Fig. 3 Fixed versus flexible water fees. Note: Own calculation based on Swiss Federal Council (2017) and SFOE (2018a, b)

calculate the resource rent (RR) as the revenue (R) net of production cost $(C)^{15}$ :

$$
\mathrm{RR}_{i}=\mathrm{R}_{i}-\mathrm{C}_{i}
$$

Therefore, the annual water fee payments for each plant $i$ correspond to

$$
\mathrm{WF}_{i}=r\left(\mathrm{R}_{i}-\mathrm{C}_{i}\right)=r \mathrm{RR}_{i} .
$$

The tax level $r$ needs to be determined such that the expected water fee revenues are kept constant at the current level. For the given set of fuel and carbon price developments-and assuming that producers making net losses pay zero tax-we find that $r=38.7 \%{ }^{16}$

In the case of a tax on resource rent, resource owners bear a much larger part of the market risk. Compared to the water fee regimes, the tax regime has two significant differences. First, it not only considers changing revenues

\footnotetext{
${ }^{15}$ Data sources and construction of revenue and costs are described in Sects. 2.2 and 2.3.

16 This is comparable to the $37 \%$ tax level in Norway (OECD, 2019). If we allowed water fee payments to become negative (i.e., producers receive payments when their production costs exceed their market revenues), the necessary tax level would be $48.9 \%$.
} 
(such as the flexible water fee) but also considers the cost side. At this point, it should be explicitly pointed out that the tax on the resource rent can be credited to the cost of equity, so a minimum return on equity is guaranteed. Second, it takes into account the considerable heterogeneity across power plants. The tax on the resource rent is based directly on the economic value of water as a resource and, therefore, has a significantly improved allocative efficiency compared to the current system. ${ }^{17}$

Banfi and Filippini (2010) highlighted the fact that with a tax on resource rent, a plant has an incentive to increase cost through operational inefficiencies in order to forego any resource rent payment. They suggested that a benchmark of cost efficiency thus is necessary to ensure equitable taxation. While any practical implementation of a resource rent tax therefore incorporate checks to ensure efficiency, such concerns are less relevant for the modelling of this study: We operate with ex-post data, meaning data stemming from a regulatory framework with a fixed water fee system, where plants had an incentive to operate at cost efficiency.

\subsection{Impact of market developments on water fees and profits}

As is obvious from the previous sections, the profit prospects are key to the assessment. In the following, we give a brief overview of how companies' profits depend on price developments and water fee regimes.

A hydropower company's net profit is determined by its revenue net of production cost and water fee payments:

$$
\pi_{i}(\boldsymbol{p})=\mathrm{R}_{i}(\boldsymbol{p})-\mathrm{C}_{i}-\mathrm{WF}_{i}(\boldsymbol{p}),
$$

where $\boldsymbol{p}$ contains fuel and carbon prices, indicating that a company's revenues and-for the flexible regimeswater fee payments depend on the market development. In the case of a flexible water fee regime, this is a direct link via the RMP; in the case of a tax on the resource rent, it is an indirect link via the impact on revenues.

Consequently, a change in fuel and carbon prices has the following consequences for companies' net profits:

$$
\frac{\partial \pi_{i}(\boldsymbol{p})}{\partial p}=\frac{\partial \mathrm{R}_{i}(\boldsymbol{p})}{\partial p}-\frac{\partial \mathrm{WF}_{i}(\boldsymbol{p})}{\partial p},
$$

where both parts of the right-hand side are positive. In other words, if fuel and carbon prices increase, revenues but also water fee payments increase. Thus, flexible water fee regimes have an ambiguous impact on companies' profits.
Importantly, water fees do not affect the operating decision of companies as they are perceived as fixed costs in the short run, meaning, as long as no investment decisions have to be made. Thus, water fee regimes do not directly affect wholesale market electricity prices and operational decisions. In each of the four market scenarios in Table 1, the companies will obtain the same market revenue. Therefore, profit differences within a market scenario are solely the result of the different water fee regimes.

In contrast, water fees have an impact on long run investment decisions of companies as they influence (expected) net profits, given a likelihood for each market scenario that the expected profit across all potential market developments will differ according to the water fee regimes. Thus, water fee regimes can impact the available production capacities and, therefore, wholesale electricity market prices in the long run.

Similar, increases in fuel or carbon prices will also alter investment incentives for all market participants and therefore could alter long run market developments (i.e. higher carbon prices may lead to a faster shift towards renewable generation changing the market price structure).

\section{Findings: the impact of different water fee design options}

\subsection{The resource user's perspective}

We assume that costs net of water fees remain at their $2015 / 16$ levels $^{18}$ and use the simulated revenues to calculate net profits. Figure 4 shows the net profits per MWh of hydropower in 2025 for the different scenarios and water fee regimes.

Figure 4 illustrates the following: First, we observe that market impact dominates the impact of water fees. In situations where electricity prices are high, the lower quartile clearly lies above zero; in fact, more than $75 \%$ of all plants in the sample make a profit-even if water fee levels are very high. If, on the other hand, electricity prices are low, the median falls below zero and more than half of the plants in the sample make a loss-again independently of the water fee regime.

Second, the results for all three water fee regimes are within the same range. None of the regimes lead to a completely different net profit structure. This also hinges on the choice of design parameters for the respective policies, meaning the tax rate or the slope of the flexible water fee.

\footnotetext{
${ }^{17}$ In fact, Banfi et al. (2004) describe the tax on the resource rent as being the most efficient tax in terms of economic criteria such as allocative efficiency or horizontal or vertical equality.
}

\footnotetext{
${ }^{18}$ Again, we use real 2015 values, without inflation or changes in the exchange rate.
} 


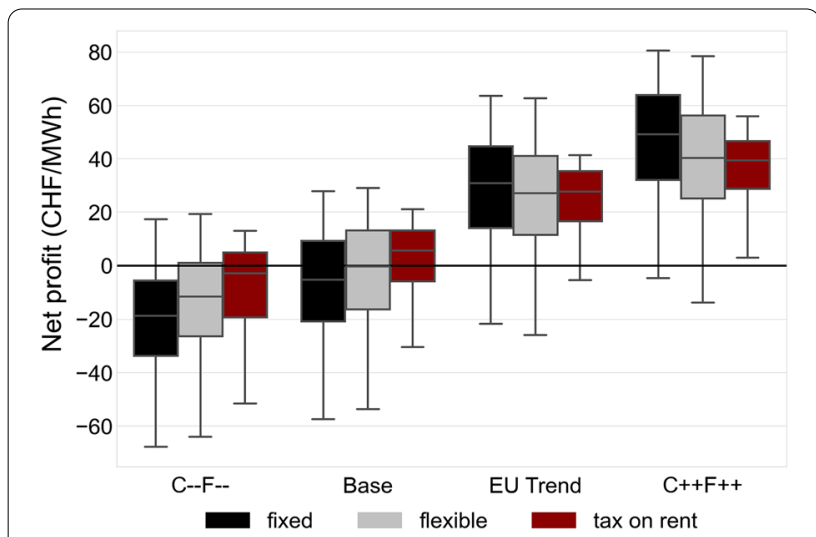

Fig. 4 Boxplots of unit net profits in 2025 for market scenarios and water fee regimes. Note: Boxes include median, 25th and 75th percentiles. Whiskers are defined as 1.5 times the interquartile range. Outliers are not shown. The market revenue for each company for a given market scenario is independent from the water fee regime and differences shown within the scenarios are solely the result of the different water fee regimes

Third, in the low-price scenarios, companies are better off with a tax on the resource rent, followed by a flexible water fee and a fixed water fee. When electricity prices are low, the flexible approach leads to lower water fee payments and higher net profits. In contrast, in the high price scenarios, companies are better off with the current fixed price scenario. In the case of a tax on the resource rent and the flexible water fee approach, they have to pay higher fees and suffer from lower profits as a result.

Fourth, for the Base scenario market development, the level of water fees determines whether the median hydropower plant is profitable or not. In such a case, the electricity market price is at a level of slightly above $40 \mathrm{CHF} / \mathrm{MWh}$. Within this range of around 40 to $60 \mathrm{CHF} / \mathrm{MWh}$, costs without water fees correspond to revenues. Consequently, water fees can make the difference between profit and loss.

Fifth, there is a large variability between plants, as seen by the size of the boxplots and whiskers (Fig. 4 does not include outliers). Below, we describe the results for individual plants in detail.

Sixth, the range of net profit is the smallest in the resource rent case. This result stems from the design of the policy since companies with higher rents need to pay more compared to companies with lower rents, resulting in a convergence of net profits.

So far, we have focused on aggregated impact, but there are large differences in unit production costs and revenue possibilities between companies. Figure 5 shows the individual results for all the companies in the sample, enabling a more detailed analysis.

A closer look at the individual companies shows that the variability across companies is larger than the

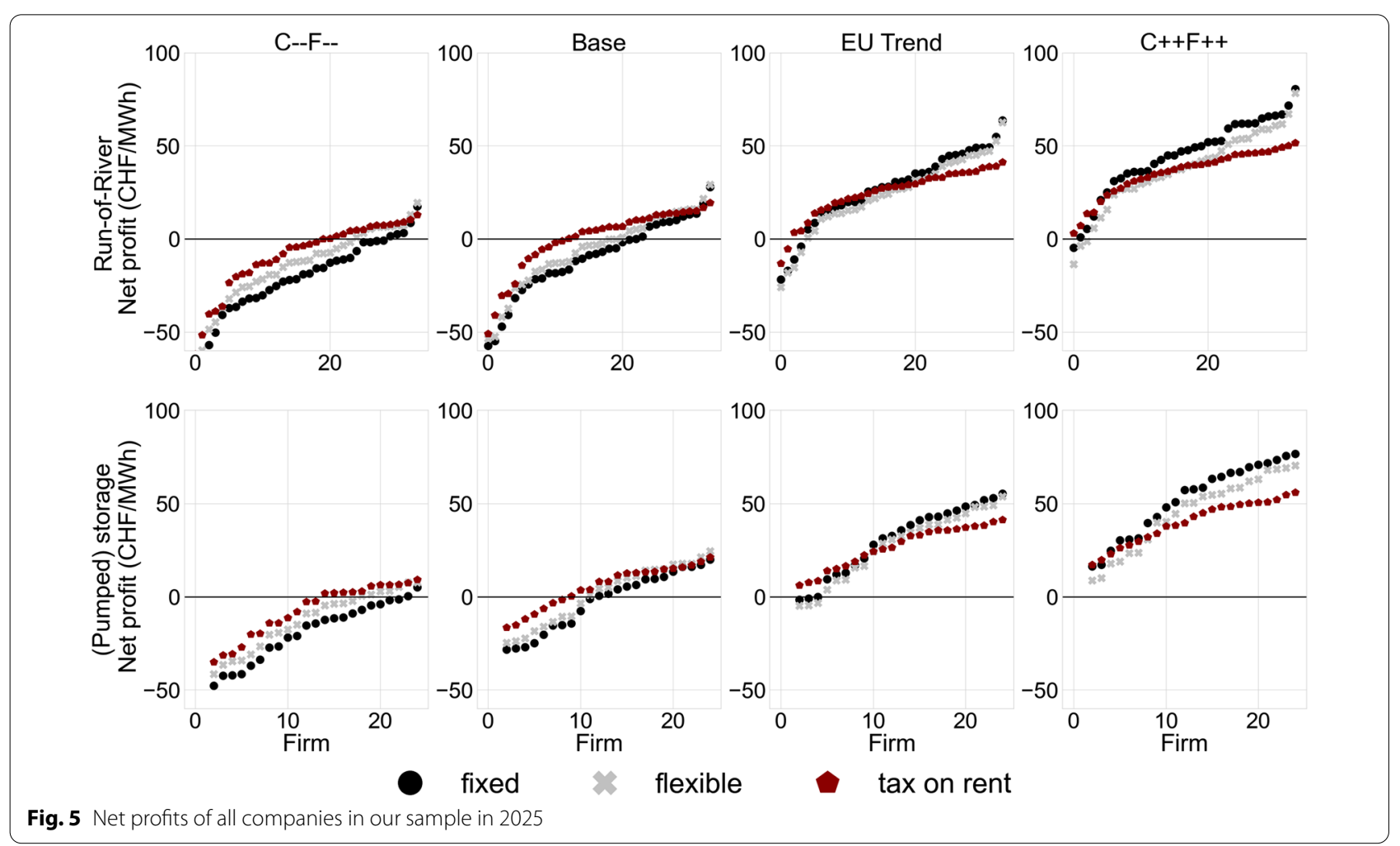




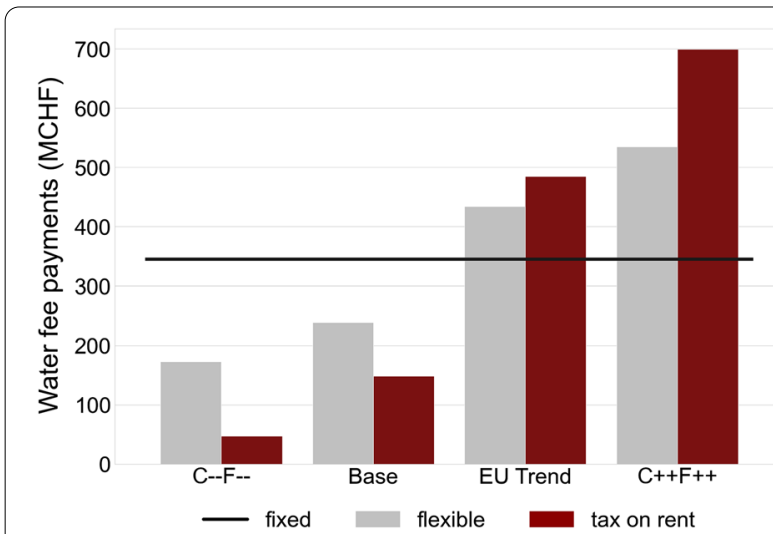

Fig. 6 Revenues from water fees for different scenarios 2025. Note: As described in Sect. 2.2, our sample covers only around 63\% of total hydropower production. Analogously, the water fee payments in our sample amount to around $63 \%$ of payments observed

variability induced by different water fee levels. Nevertheless, within each price scenario, the water fee level makes the difference between profit or loss for several companies. Finally, the graph clearly shows how a tax on the resource rent decreases the variability in net profit between plants as, by definition, a tax of $100 \%$ would absorb the entire resource rent, leading to zero net profit.

In summary, we find that the influence of market developments dominates the impact of water fee regimes on the profitability of hydro power plants, while the variability across plants is extensive. Nevertheless, our results also show that water fee regimes that take market outcomes into account can reduce some of the pressure on the profitability of hydropower. However, this can only be part of, and not the entire solution. Also, the more flexible a regime's design, the more pronounced this effect.

\subsection{The resource owner's perspective}

A new water fee regime would affect not only producers but also resource owners, namely the Swiss cantons and municipalities which receive water fee revenues.

\subsubsection{Changes in water fee payments}

Figure 6 shows the water fee payments for different price scenarios and water fee regimes. In line with the companies' perspective, we find that in years with high electricity prices, revenues are higher with a flexible water fee regime than under today's water fee regime. However, in years with low electricity prices, revenues can be substantially lower. In theory, they could even be negative in the case of a tax on resource rents. However, in reality, water fee payments are set to zero when company costs exceed revenue.
For the high price scenarios (EU Trend and $C++F++$ ), revenues from water fee payments can as much as double when the design considers changing market conditions. This impact is significantly more pronounced for a tax on the resource rent as compared to a flexible water tax based on a reference market price.

For the low-price scenarios, however, revenues significantly decrease, and differences between the various regimes are considerable. In the case of a flexible water fee, revenues decrease by up to $40 \%$ in years with low electricity prices. When levying a tax on the resource rent, we observe that revenues can drop by almost $90 \%{ }^{19}$

\subsubsection{The impact of ownership structures}

Our analysis distinguishes between producers paying the water fees and an aggregate of resource owners receiving the payments. However, in reality, these ownership structures are more complicated (see Hediger et al., 2019a, b, for a more detailed analysis). In the following section, we provide a qualitative assessment of the implications of real ownership structures on the results and the practicability of a tax on resource rents in the Swiss context.

In Switzerland, most hydropower companies are owned by cantons and municipalities. This makes them the owners of both the resource and the company (e.g., the Canton of Bern owns $52 \%$ of $B K W,{ }^{20}$ see Cometta et al., 2016). However, the characteristics differ between cantons. Cantons rich in hydro resources are mostly situated in the mountains, so mountainous cantons are the primary beneficiaries of water fee payments. Cantons owning most of the hydropower companies, on the other hand, are usually financially strong low-land cantons (the Canton of Zurich, e.g., directly owns 18.3\% of Axpo, and an additional $18.4 \%$ indirectly through the Canton's

\footnotetext{
${ }^{19}$ In our main results, we restrict the tax on the resource rent to be positive. However, in theory, this tax can become negative if companies make losses. In such a case, the tax level would need to be set at $48.9 \%$ in order to equalize the average water fee revenues across scenarios. In other words, in good years companies would need to pay almost $50 \%$ of their resource rents to the state. In return, this would imply that in the lowest-price scenario $(\mathrm{C}-\mathrm{F}-)$ resource owners such as the cantons and municipalities would need to pay more than CHF 100 million to compensate, in part, for the net losses of companies (detailed results are available on request).

If extrapolated to the universe of Swiss hydro power plants, this amount would increase to around CHF 165 million (as our sample covers around $63 \%$ of total hydropower production). This number is significantly larger than the market premium which is currently being paid by the Swiss government to large hydro power plants which have to sell their electricity below production cost. In 2018 and 2019, companies received CHF 110 million and CHF 65 million, respectively. Today, the Swiss federal government is offering compensation for these losses with revenues from electricity network surcharges, whereas the cantons or municipalities that profited before from high water fees do not contribute to the compensation payments.

20 Bernische Kraftwerke.
} 
own power company, $\mathrm{EKZ}^{21}$ (Cometta et al., 2016)); lowland cantons pay the water fees indirectly. Consequently, water fees induce a monetary transfer from the (richer) low-land cantons to the (poorer) mountain cantons.

Given that water fee payments make up roughly ten percent of national fiscal equalization, the amount of this additional transfer is substantial and, for some cantons and municipalities, a sizable proportion of their total budget. A drastic cut in water fee revenue through flexibilization would trigger severe financial problems. For these reasons, mountainous cantons oppose the flexibilization of water fees as they fear lower revenues, while some low-land cantons would benefit from flexibilization since their companies would not make such high losses. For a more detailed discussion on the feedback effects caused by ownership structures, see Betz et al. (2018).

\subsection{The impact of different RMPs on a flexible water fee regime}

In a flexible water fee regime, payments depend on the definition of the RMP (see Eq. 2). Thus, the RMP is a design element in itself and has an impact on water fee levels. In the following section, we consider three different ways (options) of defining the RMP and assess the respective impact.

\subsubsection{How to determine the RMP?}

Currently, the most likely policy option on which to base the results defines the RMP as the average unit revenue ${ }^{22}$ (uniform). An alternative option would be to define it as the annual average spot market price of electricity (spot), which would be the most straightforward, transparent option. However, this would not account for the fact that some hydropower plants shift their production to hours with high electricity market prices. Another alternative would be to use the average unit revenue per technology (differentiated) as the RMP. In this case, we have different RMPs and, therefore, water fee levels for run-of-river and (pumped) storage plants, respectively. While this option accounts for the varying revenue options of different plant types, it is more complex to implement and less transparent than the other two options (Table 4).

In summary, when defining the RMP, policymakers face a trade-off between being transparent/straightforward and taking account of the different realities of individual producers. By analyzing the three options, we can provide an initial estimation of the magnitude of the impact.

\footnotetext{
${ }^{21}$ Elektrizitätswerke des Kantons Zürich.

22 In reality, not only revenues from the wholesale market but also from the markets of "ancillary services" (SDL) and "Certificate of origin" (HKN) would be taken into account. However, for our analysis we only consider wholesale market revenues.
}

Table 4 Reference market price options

\begin{tabular}{ll}
\hline Option & Definition of reference market price (RMP) \\
\hline Spot & Annual average spot market price \\
Uniform & $\begin{array}{l}\text { Annual average unit revenue for an average } \\
\text { hydropower plant }\end{array}$ \\
Differentiated & Unit revenue differentiated by type \\
\hline
\end{tabular}

Before turning to the impact of different reference price definitions on water fee payments, we analyze how much they differ. Table 2 (in Sect. 3.1) shows the RMP for 2025 for the three options and four market developments. It is important to remember that spot prices are very close to unit revenues for run-of-river plants while unit revenues for (pumped) storage plants are significantly higher. Consequently, unit revenues of an average plant are slightly higher than spot market prices as they include characteristics of both plant types.

\subsubsection{Impact of reference market prices: uniform water fees favor (pumped) storage plants}

Different water fee levels occur when we combine the different RMPs with a flexible water fee design. Figure 7 shows the median water fee payments by plant type for the different reference price definitions and market developments in 2025.

We find that the results are very similar across different RMP options: The current definition of the RMP as average unit revenue leads to slightly higher water fee payments than the simpler option of taking the spot prices. Using differentiated RMPs would be favorable to runof-river plants but disadvantageous to (pumped) storage plants, which would have to pay somewhat higher water fees.

\subsubsection{Distribution implications}

Again, there are distribution implications for the cantons since (pumped) storage plants are located mainly in mountain regions. When water fees are differentiated and account for individual revenue options, (pumped) storage plants pay more. Consequently, mountain regions suffer less from a flexible water fee regime than if they were in a situation with non-differentiated RMPs.

Flexible water fee regimes shift the risk from producer to resource owners (or from low-land cantons to mountainous regions). Differentiated reference market prices, on the other hand, increase the water fee payments for (pumped) storage plants and thus revenues for mountain regions. By differentiating the RMP, the shift in risk from producers to resource owners still prevails, but the shift from low-land to mountain cantons is reduced. The extent to which this impacts the monetary flow between 

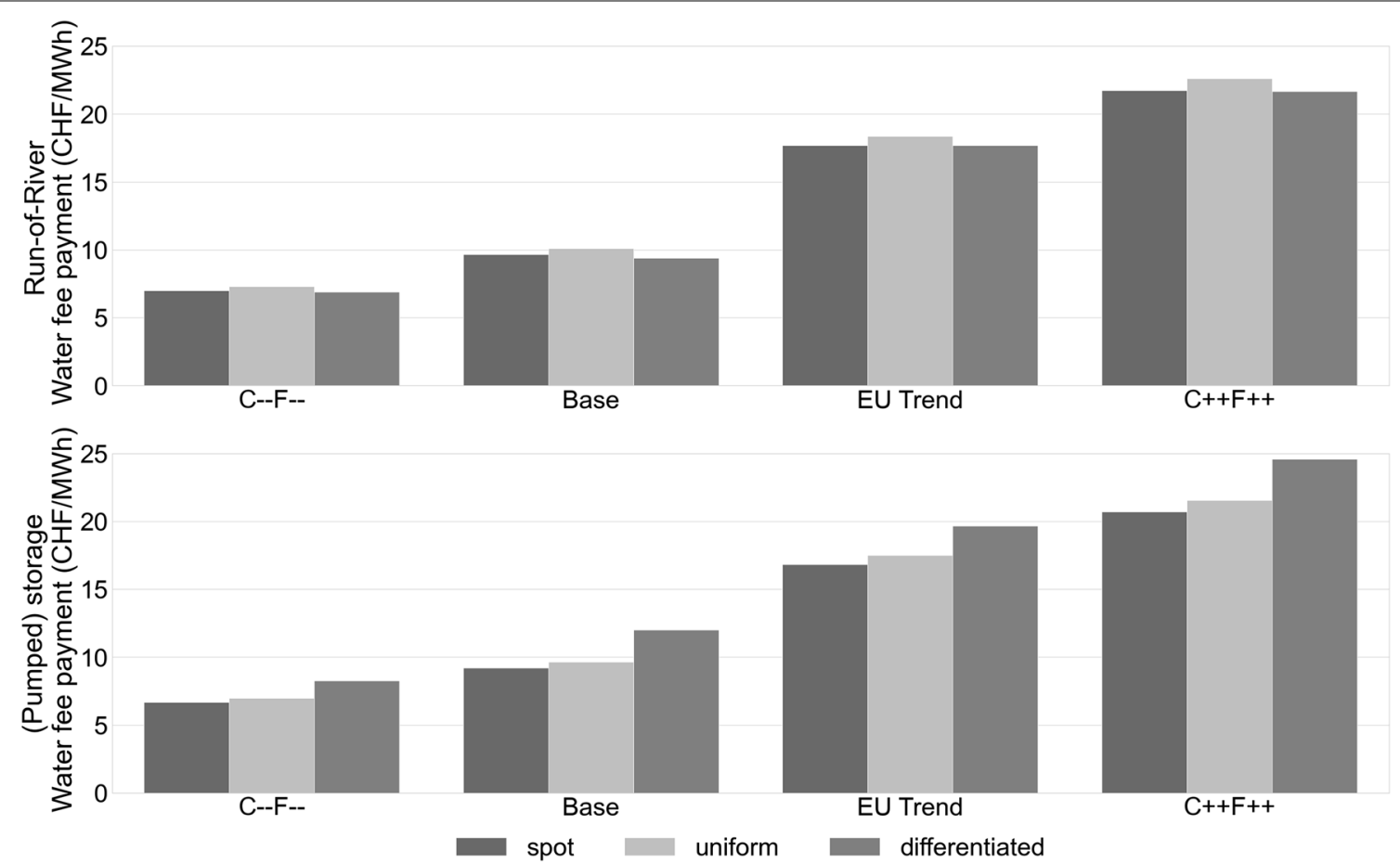

Fig. 7 Water fee payments for different reference market price options (median). Note: The market revenue for each company for a given market scenario is independent from the water fee regime and the differences shown are solely the result of the different water RMP designs

cantons (and to other shareholders) is beyond the scope of this paper.

\subsection{Summary: risk shift from resource user to resource owner}

As discussed in the previous sections, the change from fixed water fees to flexible regimes where the water fee level is market-driven leads to a shift of the market risk from resource users (companies or low-land cantons, which own most of the companies) to resource owners (cantons or municipalities, often in mountain regions). With flexible water fees, this risk shift can be (partially) compensated using reference market prices differentiated by technology.

Table 5 summarizes the impact of different design options on the market risk for different stakeholders. We focus on years with low electricity prices as these are critical in the current discussion.

\section{Discussion and conclusions}

Hydropower has a key role in Switzerland's electricity system and represents an essential pillar of the envisioned transition towards a future electricity system that is expected to be dominated by power generation from intermittent renewable energy sources such as wind and solar power. Given the importance of hydropower in a multitude of further domains such as agriculture, tourism, flood control, biodiversity, and environmental services, and the often-resulting significant local economic implications, the future role of hydropower is a reoccurring theme in political debates. The assessment presented in this paper of the potential impact of different water fee reform options aims to contribute to these debates and highlights the challenges inherent in altering a status-quo framework.

The primary result of a flexible fee- or tax-based approach is a shift in market risk from the producers to the resource owners (in this case, mostly the Swiss cantons and municipalities). This is straightforward given the basic properties of a flexible water fee design. The feedback effects to local structures, producers, and the Swiss electricity system in general are less straightforward (see, e.g., Hediger et al., 2019b for an assessment of local effects in the canton of the Grisons). As our assessment shows, electricity market developments can easily dominate the impact of the different regimes. Furthermore, the high heterogeneity between Swiss hydro companies translates into a set of plants that make profits and others that make losses in every scenario combination. Thus, beside the risk allocation, the broader market and 
Table 5 Risk shift from resource users to resource owners

\begin{tabular}{|c|c|c|c|}
\hline Regime & Market risk & RMP & Technology differences \\
\hline \multirow[t]{2}{*}{ Fixed } & - Resource owners receive constant water fee payments & & \\
\hline & - Entire market risk lies with the resource users & & \\
\hline \multirow[t]{8}{*}{ Flexible } & - Water fee payments depend on market prices & Differentiated & In low-price years: \\
\hline & & & $\begin{array}{l}\text { - (Pumped) storage plants have a relative advan- } \\
\text { tage }\end{array}$ \\
\hline & & & - Run-of-river plants pay relatively more \\
\hline & & & - Relatively higher revenues for low-land cantons \\
\hline & & Uniform & In low price years: \\
\hline & & & - Run-of-river plants have a relative advantage \\
\hline & $\begin{array}{l}\text { - Market risk is partly shifted from resource user to resource } \\
\text { owner }\end{array}$ & & - (Pumped) storage plants pay relatively more \\
\hline & $\begin{array}{l}\text { - In low-price years: lower revenues, especially for mountain } \\
\text { cantons }\end{array}$ & & - Relatively higher revenues for mountain cantons \\
\hline \multirow[t]{2}{*}{ Resource Rent Tax } & $\begin{array}{l}\text { - Water fee payments depend on market prices and production } \\
\text { costs }\end{array}$ & & \\
\hline & $\begin{array}{l}\text { - Market risk is partly shifted from resource user to resource } \\
\text { owner }\end{array}$ & & \\
\hline
\end{tabular}

policy developments also need to be considered. In the following, we discuss them along four current topics.

First, the overall market trend is, to a large extent, shaped by European developments. Our scenario selection tried to highlight potential price pathways; however, the actual development is uncertain. While, in the long run, an increasing emission permit price might be expected to also lead to an increasing wholesale price trend, there is no guarantee that this scenario will emerge at all. Furthermore, even if a price increase occurs, this may coincide with prolonged low-price periods andespecially important for pumped storage plants-a lowprice spread between peak and off-peak periods due to the interplay between renewable generation and conventional units (i.e., see Schlecht \& Weigt, 2016). While a shift towards a more flexible water fee regime would reduce the overall uncertainty hydropower companies face, the bulk of the market risk would remain outside of the influence of Swiss companies and policy makers.

Second, the envisioned full market liberalization ${ }^{23}$ will have a more direct influence on Swiss hydropower companies. Today, a share of hydro generation is sold to captive customers, thereby providing a cost recovery insurance for those suppliers. A full liberalization of small-scale customers would open Swiss hydro generation to market competition. As our assessment shows, a share of the investigated companies has unfavorable cost structures and experiences losses even in more favorable

${ }^{23}$ See www.bfe.admin.ch/bfe/de/home/news-und-medien/medienmitteilun gen/mm-test.msg-id-81068.html and www.newsd.admin.ch/newsd/message/ attachments/63715.pdf. price scenarios. While such firms could prevail with a captive customer base, they have a higher risk in an open market environment. Such firms would benefit from a tax approach as this would be directly linked to their profit structure. However, they would benefit only to a very small extent from a flexible water fee regime: In times of low market prices, their unfavorable cost structures will lead to high losses even with a reduced fee and in times of high market prices the fee level will increase and reduce their profitability prospects.

Third, another political concern is the Swiss supply situation during the winter months. Switzerland is usually import-dependent during those months, and the phase-out of nuclear stations is expected to increase the import share further. To increase winter production, the Swiss Federal Council has proposed the introduction of a storage reserve (SFOE, 2018b) and supports measures to increase hydro generation by $2 \mathrm{TWh} .{ }^{24}$ An adjustment of the water fee regime would not impact the incentives for hydropower companies to maximize their supply during high-priced winter hours as the fee itself has no impact on the operational incentive structure. However, the altered risk allocation could change long-term investment prospects.

As indicated above, the market uncertainty will likely remain the dominant factor, but in price corridors of up to $60 \mathrm{CHF} / \mathrm{MWh}$, the fee design can make the difference between profitability and loss for some companies-and
${ }^{24}$ See $\quad$ www.bfe.admin.ch/bfe/de/home/news-und-medien/medienmitteilun gen/mm-test.msg-id-81068.html and www.newsd.admin.ch/newsd/message/ attachments/63715.pdf. 
Table 6 Notation used for the Swissmod model

\begin{tabular}{|c|c|c|c|}
\hline \multicolumn{2}{|l|}{ Indices/sets } & \multicolumn{2}{|l|}{ Parameters } \\
\hline$n \in N$ & Power nodes & $\mathrm{mc}$ & Marginal cost \\
\hline$l \in L$ & Power lines & $d$ & Demand \\
\hline$t \in T$ & Time periods (hours) & res & Renewables in-feed \\
\hline$c p \in C P$ & Conventional power plants & $\eta_{\text {hp }}^{\text {Turb }}$ & Production equivalent $\left[\mathrm{MWh} / 1000 \mathrm{~m}^{3}\right]$ \\
\hline$h p \in H P$ & Hydropower plants & $\eta_{\text {hp }}^{\text {Pump }}$ & Pumping efficiency factor \\
\hline$w n, \overline{w n}, \underline{w n} \in W N$ & Water nodes $\mathrm{CH}$ (above, below) & $\eta_{\mathrm{hp}}^{\mathrm{rt}}$ & Pumping round-trip efficiency \\
\hline $\mathrm{CO} \in \mathrm{CO}$ & Countries & inj & Natural inflow to water node $\left[1000 \mathrm{~m}^{3}\right]$ \\
\hline Matrices & & chp & Combined heat and power \\
\hline inc $_{n, l}$ & Power grid incidence $\in\{0,1,-1\}$ & $g_{\mathrm{cP}}^{\max }$ & Generation capacity \\
\hline Variables & & turb $\max _{\mathrm{mp}}$ & Turbine capacity [MW] \\
\hline G & Electricity generation & pump $p_{\mathrm{hp}}^{\max }$ & Pump capacity [MW] \\
\hline Turb & Discharge (in water for $\mathrm{CH}$, in electricity for $\mathrm{EU}$ ) & avail & Availability conventional power plants \\
\hline Pump & Pumping (in water for $\mathrm{CH}$, in electricity for $\mathrm{EU}$ ) & $s^{\max }$ & Storage capacity [MW for $\mathrm{EU}, 1000 \mathrm{~m}^{3}$ for $\left.\mathrm{CH}\right]$ \\
\hline Cur & Curtailment of renewables & turb profile & Run-of-river profile (for EU) \\
\hline F & Line flow & turb & Dam generation per year (for EU) \\
\hline$S$ & Storage level & susceptance, & Line susceptance \\
\hline WI & Water inflow & voltbase & Line voltage base \\
\hline WO & Water outflow & $f_{l}^{\max }$ & Line capacity \\
\hline Spill & Spillage & securitymargin & Line security margin \\
\hline Transfer & $\begin{array}{l}\text { Water transferred to other water node (without } \\
\text { turbining or pumping) }\end{array}$ & & \\
\hline$x$ & Phase angle difference & & \\
\hline
\end{tabular}

could, therefore, also tip investment decisions-especially for retrofit investments. As both a flexible fee and a tax would actually lower income prospects in favorable market conditions, a shift towards these conditions might reduce overall investment incentives, assuming that in unfavorable market conditions investment prospects are likely to remain negative regardless of the water fee regime. On the other hand, the historic development of the fixed fee has shown that also this level can be adjusted, especially in times of favorable market prices. Such an adjustment would lead to similar income effects for suppliers as a more flexible regime-however with the downside of not automatically reverting in case of price reductions.

Fourth, as explained in Sect. 2.1, the overall profitability of Swiss hydropower has already been a concern in recent years. As a consequence of the challenging liquidity situation caused by the decreasing market prices, a temorary support system has been initiated. The socalled 'Marktprämie Grosswasserkraft' (market premium for large hydropower projects) provides financial support for plants that have to sell at prices below cost and is refinanced via a surcharge on network tariffs. ${ }^{25}$ It is limited

\footnotetext{
${ }^{25}$ For further details, see https://www.bfe.admin.ch/bfe/de/home/foerderung/ erneuerbare-energien/marktpraemie-grosswasserkraft.html.
}

for the period 2018 to 2022, and in the first three years it paid out CHF 101, 65, and 85 million respectively.

Our assessment shows that implementing a flexible fee system could, potentially, have reduced those payments as a share of companies would have been pushed closer to break-even in the lower-priced scenarios. A negative tax on resource rents (i.e., the resource owner pays the companies to compensate some of their losses incurred by low electricity prices) would have led to (hypothetical) payments that are comparable with the payments for the market premium.

Both the envisioned support mechanism for the $2 \mathrm{TWh}$ increase in winter production and the market premium indicate that Swiss policy makers are willing to spend money on Swiss hydropower to maintain and extend its generation capabilities. As the adjustments of the water fee regime will necessarily come with a reallocation of risks, financial opportunities, and burdens, one can expect opposition by those companies, cantons, and municipalities that would lose income. At the same time, our assessment shows that a reform will likely have a rather limited overall impact on the profitability of Swiss hydropower. Together, this setting suggests that a continuation of the status quo might-from a political point of view - not be an unlikely option. However, 
Table 7 Mathematical formulation of the Swissmod model

\begin{tabular}{|c|c|c|c|}
\hline & $\min \sum_{\mathrm{cp} . t} m c_{\mathrm{cp}} G_{\mathrm{cp}, t}$ & & $(1)$ \\
\hline $\begin{array}{l}\text { (Nodal) demand- } \\
\text { supply balance }\end{array}$ & $\begin{array}{l}d_{n, t}{ }_{\mathrm{cp}, t} \\
+\sum_{\mathrm{cp} \in n} G_{\mathrm{cp}, t}+\sum_{\mathrm{hp} \in n^{\mathrm{CH}}}\left(\eta_{\mathrm{hp}}^{\text {Turb Turb }} \mathrm{hpp}_{\mathrm{hp} t}^{\mathrm{CH}}-\eta_{\mathrm{hp}}^{\text {Pump Pump }}{ }_{\mathrm{hp}, t}^{\mathrm{CH}}\right) \\
+\sum_{\mathrm{hp} \in n^{\mathrm{EU}}}\left(\operatorname{Turb}_{\mathrm{hp}, t}^{\mathrm{EU}}-\text { Pump }_{\mathrm{hp}, t}^{\mathrm{EU}}\right)+\operatorname{res}_{n, t}-\mathrm{Cur}_{n, t}-\sum_{l} \text { inc }_{n, l} F_{l, t}\end{array}$ & $\forall n, t$ & $(2)$ \\
\hline Capacity limit & $\operatorname{chp}_{\mathrm{cp}, t} \leq G_{\mathrm{cp}, t} \leq g_{\mathrm{cp}}^{\max }$ avail $_{\mathrm{cp}, t}$ & $\forall c p, t$ & (3) \\
\hline $\begin{array}{l}\text { Curtailment limit } \\
\text { Hydro } \mathrm{CH} \text { : }\end{array}$ & $\operatorname{Cur}_{n, t} \leq \operatorname{res}_{n, t}$ & $\forall n, t$ & (4) \\
\hline Turbine capacity limit & $\eta_{\mathrm{hp}}^{\text {Turb }} \operatorname{Turb}_{\mathrm{hp}, t}^{\mathrm{CH}} \leq \operatorname{turb}_{\mathrm{hp}}^{\max }$ & $\forall h p \in C H, t$ & (5) \\
\hline Pump capacity limit & $\eta_{\mathrm{hp}}^{\text {Pump }}$ Pump $_{\mathrm{hp}, \mathrm{C}}^{\mathrm{CH}} \leq$ pump $_{\mathrm{hp}}^{\max }$ & $\forall h p \in C H, t$ & (6) \\
\hline Storage balance & $S_{\mathrm{wn}, t}=S_{\mathrm{wn}, t-1}+\mathrm{WI}_{\mathrm{wn}, t}-\mathrm{WO}_{\mathrm{wn}, t}$ & $\forall w n \in C H, t$ & (7) \\
\hline Water inflow & $\mathrm{Wl}_{\mathrm{wn}, t}=\operatorname{inj}_{\mathrm{wn}, t}+\sum_{\mathrm{hp} \in \overline{\mathrm{Wn}}} \operatorname{Turb}_{\mathrm{hp}, t}^{\mathrm{CH}}+\sum_{\mathrm{hp} \in \underline{\mathrm{wn}}} \mathrm{Pump}_{\mathrm{hp}, t}^{\mathrm{CH}}+\sum_{\mathrm{hp} \in \overline{\mathrm{Wn}}}$ Spill $_{\mathrm{hp}, t}+\sum_{\overline{\mathrm{wn} \in \mathrm{wn}}}$ Transfer $_{\overline{\mathrm{wn}}, \mathrm{wn}, t}$ & $\forall w n \in C H, t$ & (8) \\
\hline Water outflow & $W_{w n, t}=\sum_{h p \in w n} \operatorname{Turb}_{h p, t}^{C H}+\sum_{h p \in \overline{w n}}$ Pump $_{h \mathrm{hp}, t}^{C H}+\sum_{h p \in w n}$ Spill $_{h p, t}+\sum_{w n \in w n}$ Transfer $_{w n, w n, t}$ & $\forall w n \in C H, t$ & (9) \\
\hline Storage limit & $S_{\mathrm{wn}, t} \leq s_{\mathrm{wn}}^{\max }$ & $\forall w n \in C H, t$ & $(10)$ \\
\hline \multicolumn{4}{|c|}{ Hydro EU (i.e., neighbors): } \\
\hline Turbine capacity limit & $\operatorname{Turb}_{\mathrm{hp}, \mathrm{t}}^{\mathrm{EU}} \leq \operatorname{turb}_{\mathrm{hp}}^{\max }$ & $\forall h p \in E U, t$ & $(11)$ \\
\hline Pump capacity limit & Pump $\mathrm{EU}_{\mathrm{hp}, \mathrm{t}} \leq \mathrm{pump}_{\mathrm{hp}}^{\max }$ & $\forall h p \in E U, t$ & (12) \\
\hline Storage level & $S_{c o, t}=S_{c o, t-1}+\sum_{h p \in c o}\left(\eta_{h p}^{r t} P_{u m p}^{E U}-T_{h p, t}^{E U} \operatorname{Turb}_{h p, t}^{E U}\right)$ & $\forall c O \in E U, t$ & (13) \\
\hline Storage limit & $S_{C O, t} \leq s_{C O}^{\max }$ & $\forall c O \in E U, t$ & (14) \\
\hline $\begin{array}{l}\text { Run-of-river } \\
\text { generation profile }\end{array}$ & $\sum_{h p \in c o} \operatorname{Turb}_{h p, t}^{E U} \leq$ turb $_{c 0, t}^{\text {profile }}$ & $\forall c O \in E U, t$ & $(15)$ \\
\hline $\begin{array}{l}\text { Dam's annual } \\
\text { generation limit }\end{array}$ & $\sum_{t, h p \in c o} T_{u r b}^{E U}{ }_{h p, t} \leq$ turb $_{c o}^{\text {year }}$ & $\forall C O \in E U$ & (16) \\
\hline \multicolumn{4}{|l|}{ Electricity grid: } \\
\hline Line flow & $F_{l, t}=$ susceptance $\sum_{n}$ inc $_{n, l} X_{n, t}$ voltbase & $\forall I, t$ & $(17)$ \\
\hline Slack bus & $x_{n=1, t}=0$ & $\forall t$ & (18) \\
\hline Line limits & $\left|F_{l, t}\right| \leq f_{l}^{\max }(1-$ securitymargin $)$ & $\forall /, t$ & (19) \\
\hline
\end{tabular}

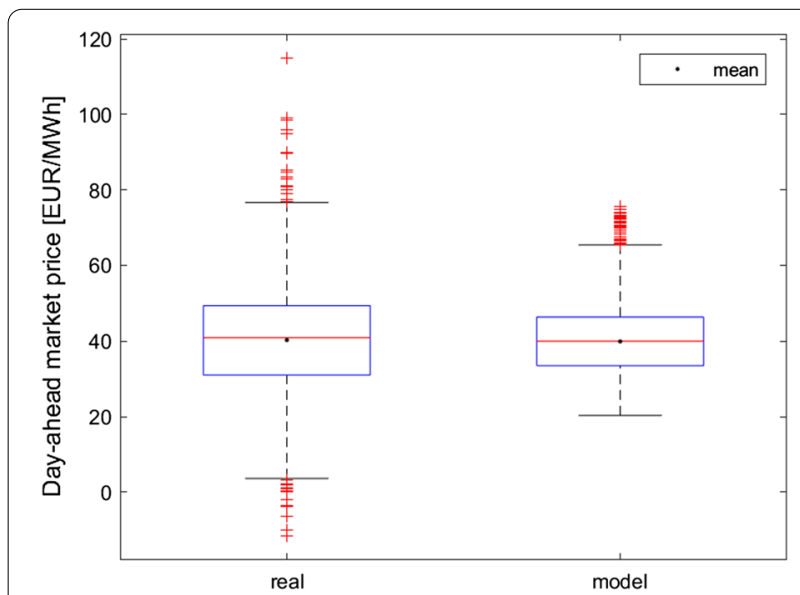

Fig. 8 Comparing observed ("real") and simulated ("model") day-ahead market prices for Switzerland for 2015. Note: Boxplots for hourly prices in EUR/MWh. Real market prices from EPEX SPOT SE subsidizing hydropower plants with revenues from network surcharges is not a long-term solution but should be replaced by a more transparent policy design.

To achieve an adjustment of the current water fee regime before the required legal renewal in 2024, policy makers need to take into account the risk distribution between the different parties involved and their ability to manage changing income levels. Specifically, this raises the question of which of the players (i.e., hydropower plants, cantons, and/or municipalities) are best able to cope with such risks. From a resource owner perspective, it might be necessary to introduce complementing compensation mechanisms for cantons and municipalities which depend on the income from water fees. From a resource user perspective, companies can hedge market price risks in the short run through the forward electricity market. However, there is no long-term forward market and there are no counterparties to hedge long-term risk. Therefore, additional regulations in the form of a 
cash reserve might be needed, where a share of profits from periods with high electricity prices covers losses when electricity prices are low. This reserve would ensure that the gains generated in good times will be banked for times of low electricity prices (or reinvested). Such a mechanism would ensure that the gains incurred by public companies or jurisdictions would not be used to compensate in other areas (i.e., as dividends or for tax shortfalls).

\section{Appendix A: Swissmod Model description}

Swissmod (Schlecht \& Weigt, 2014) is a classical dispatch model for Switzerland and its neighboring countries of Germany, Austria, France, and Italy. The model (notation and mathematical formulation) is outlined in Tables 6 and 7. In the Swissmod version used in this paper, the objective of the model is to minimize the total system cost over the annual time horizon considered (Eq. 1). The costs are determined by the marginal costs of the conventional power plants which are defined by fuel prices, $\mathrm{CO}_{2}$ price, plant emission factor, and plant efficiency. Electricity demand and supply from conventional, renewable, or hydropower plants (considering power flows) must be balanced at each node (location) in each hour (Eq. 2). With its hourly time resolution, the market that Swissmod simulates corresponds to today's day-ahead wholesale markets in which hourly products (or blocks of combined hours) are traded. Hourly prices in Swissmod can be derived from the shadow price or dual variable on the nodal balance. However, these prices represent hourly nodal prices (or locational marginal prices), whereas in today's market design there is a single price per country. Therefore, the hourly day-ahead prices for each country are derived in Swissmod by calculating the average values of the hourly nodal prices per country.

Due to the importance of hydropower in Switzerland, it is modeled in great detail by considering some 400 hydropower stations (accounting for 96\% of Switzerland's hydropower generation from run-of-river, storage and pumped storage plants) with their underlying cascade structures, water flows along these cascades, and the resulting interdependencies in the cascades (Eqs. 5 to 10). Hydropower plants in Swissmod do not have a direct marginal cost but operate under an implicit consideration of their opportunity cost or water values (which can be derived from the shadow price or dual variable of the storage balance (Eq. 7)). The revenue of each hydropower plant can be calculated ex-post from the hourly power plant dispatch and the simulated hourly market prices.

Hydropower in the neighboring countries is modeled in an aggregated (country level) representation (Eqs. 11 to 16). The power flow in Switzerland and across the borders is simulated by a DC load flow approach (Eqs. 17 to 19), which provides a detailed representation of the Swiss transmission grid by dividing Switzerland into approximately 230 locations (nodes) interconnected by 400 transmission lines $(380 \mathrm{kV}$ and $220 \mathrm{kV})$. Interconnected neighboring countries are included in an aggregated, less detailed representation (using a smaller number of nodes and lines).

\section{Model calibration}

The model was calibrated for the year 2015. When comparing the observed and simulated market prices for Switzerland (Fig. 8), it can be seen that the prices are well in line with the annual average (or median). However, the prices differ in their spread (quartiles and extremes). While the simulated market prices are a good representation of the classic annual profile with higher prices in winter and lower prices in summer, they have a much lower dispersion than observed in the market. This is due to the fact that complex technical constraints (startup/shutdown, ramp-up/down, minimum up/down time), which are important in reality, are not considered in Swissmod.

\section{Abbreviations \\ CHF: Swiss francs; EU: European Union; kW: Kilowatt; MWh: Megawatt hour; RMP: Reference market price; SFOE: Swiss Federal Office of Energy; WASTA: Statistik der Wasserkraftanlagen (Hydropower plants statistics); WF: Water fee; WRG: Water Rights Act.}

\section{Acknowledgements}

See "Funding".

\section{Authors' contributions}

M.K.: Analysis and writing. R.B.: Data construction and research idea. T.G.: Data construction. M.S.: Modelling (revenue part of results) and writing. H.W.: Modelling (revenue part of results), research idea, and discussion. All authors read and approved the final manuscript.

\section{Funding}

This study is part of the cluster project "The Future of Swiss Hydropower: An Integrated Economic Assessment of Chances, Threats and Solutions" (HP Future) undertaken as part of the National Research Programme "Energy Turnaround" (NRP 70) of the Swiss National Science Foundation (SNSF). Further information on NRP 70 can be found on www.nrp70.ch. The research for this paper was carried out within the framework of SCCER CREST (Swiss Competence Center for Energy Research, www.sccer-crest.ch), which is funded by the Swiss Innovation Agency (Innosuisse) under Grant No. KTI. 1155000154.

\section{Availability of data and material}

Information can be found in Sect. 2 of this paper. Data on hydropower cost is available on request.

\section{Declarations}

Competing interests

We have no conflict of interest to declare.

\section{Author details}

${ }^{1}$ Center for Energy and the Environment (CEE), ZHAW, Bahnhofplatz 12, 8400 Winterthur, Switzerland. ${ }^{2}$ Forschungsstelle für Nachhaltige Energieund Wasserversorgung (FoNEW), University of Basel, Peter Merian-Weg 6, 
4002 Basel, Switzerland. ${ }^{3}$ Potsdam Institute for Climate Impact Research (PIK), Telegrafenberg, 14473 Potsdam, Germany.

Received: 14 October 2020 Accepted: 2 August 2021

Published online: 25 September 2021

\section{References}

Abrell, J., Eser, P., Garrison, J. B., Savelsberg, J., \& Weigt, H. (2019). Integrating economic and engineering models for future electricity market evaluation: A Swiss case study. Energy Strategy Reviews, 25, 86-106.

Banfi, S., \& Filippini, M. (2010). Resource rent taxation and benchmarking-A new perspective for the Swiss hydropower sector. Energy Policy, 38(5), 2302-2308.

Banfi, S., Filippini, M., \& Mueller, A. (2005). An estimation of the Swiss hydropower rent. Energy Policy, 33(7), 927-937.

Banfi, S., Massimo, F., Luchsinger, C., \& Müller, A. (2004). Bedeutung der Wasserzinse in der Schweiz und Möglichkeiten einer Flexibilisierung. vdf Hochschulverlag an der ETH Zürich.

Betz, R., Geissmann, T., Hediger, W., Herter, M., Schillinger, M., Schuler, C., \& Weigt, H. (2018). The future of Swiss hydropower: Distributional effects of water fee reform options. HP Future interim project report.

Betz, R., Geissmann, T., Kosch, M., Schillinger, M., \& Weigt, H. (2019). The future of Swiss hydropower: The design of variable water fees and its impact on profitability. HP Future project report. Retrieved from, https://fonew.unibas. ch/fileadmin/user_upload/fonew/Paper/HP_Future_2019_WaterFees.pdf.

Cometta, C., Kobe, C., \& Benz, A. (eds.) (2016). Umsetzung der Energiestrategie 2050 - Herausforderungen und Chancen für Staat und Wirtschaft. School of Management and Law (SML). Zurich University of Applied Sciences (ZHAW).

Canton of Grisons Chancellery. (2005). Kraftwerkbesteuerung gekündet. Standeskanzlei des Kantons Graubünden (SKG). Online: October 04, 2005. Access date: June 20, 2020. Retrieved from, www.gr.ch/DE/Medien/Mitte ilungen/MMStaka/2005/Seiten/DE_16544 i.aspx.

European Commission. (2016). EU Reference Scenario 2016. Energy, transport and GHG emissions. Trends to 2050.

Filippini, M., \& Geissmann, T. (2014). Kostenstruktur und Kosteneffizienz der Schweizer Wasserkraft. Report commissioned by the Swiss Federal Office of Energy (SFOE). Bern.

Filippini, M., \& Geissmann, T. (2018). Kostenstruktur der Schweizer Wasserkraft. Aktualisierung 2017. Report commissioned by the Swiss Federal Office of Energy (SFOE). Bern: Eidgenössisches Departement für Umwelt, Verkehr, Energie und Kommunikation UVEK.

Filippini, M., Geissmann, T., \& Greene, W. H. (2018). Persistent and transient cost efficiency-An application to the Swiss hydropower sector. Journal of Productivity Analysis, 49, 65-77.

Frauendorfer K., \& Schürle M. (2017). Das Erlöspotenzial der Schweizer Grosswasserkraft. Report commissioned by "Regierungskonferenz der Gebirgskantone".
Glachant, J.-M., Saguan, M., Rious, V., \& Douget, S. (2015). Regimes for granting the right to use hydropower in Europe. Research Report - Florence School of Regulation. European University Institute.

Hediger, W., Herter, M., \& Schuler, Ch. (2019a). The future of Swiss hydropower: Water fee-induced financial flows in Switzerland. Final Report.

Hediger, W., Herter, M., \& Schuler, C. (2019b). Royalties and fiscal equalization-The case of Swiss hydropower. In 16th IAEE European conference on energy challenges for the next decade, August 25-28, 2019. International Association for Energy Economics.

OECD. (2019). Tax Policy Reforms (2019). OECD and Selected Partner Economies. OECD Publishing.

Pineau, P.-O., Tranchecoste, L., \& Vega-Cárdenas, Y. (2017). Hydropower royalties: A comparative analysis of major producing countries (China, Brazil, Canada and the United States). Water, 2017(9), 287.

Prognos. (2012). Die Energieperspektiven für die Schweiz bis 2050. Energienachfrage und Elektrizitätsangebot in der Schweiz 2000-2050. Ergebnisse der Modellrechnungen für das Energiesystem. Report commissioned by the Swiss Federal Office of Energy (SFOE). Bern: Eidgenössisches Departement für Umwelt, Verkehr, Energie und Kommunikation UVEK.

Schlecht, I., \& Weigt, H. (2014). Swissmod-A model of the Swiss electricity market.

Schlecht, I., \& Weigt, H. (2016). Long drought ahead? The future revenue prospects of Swiss hydropower. SCCER CREST WP3 - 2016/03.

Swiss Federal Council. (2017). Erläuternder Bericht zur Änderung des Wasserrechtsgesetzes (Vernehmlassungsvorlage). Bern: Schweizerische Eidgenossenschaft. Retrieved from, https://www.admin.ch/ch/d/gg/pc/docum ents/2875/Wasserzins_Erl.-Bericht_de.pdf.

Swiss Federal Council. (2018). Botschaft zur Änderung des Wasserrechtsgesetzes (provisorische Fassung). Bern: Schweizerische Eidgenossenschaft. Retrieved from, https://www.newsd.admin.ch/newsd/message/attac hments/52433.pdf.

Swiss Federal Office of Energy, SFOE. (2016). Statistik der Wasserkraftanlagen der Schweiz für das Jahr 2015. Swiss Federal Office of Energy, SFOE.

Swiss Federal Office of Energy, SFOE. (2017). Statistik der Wasserkraftanlagen der Schweiz für das Jahr 2016. Swiss Federal Office of Energy, SFOE.

Swiss Federal Office of Energy, SFOE. (2018a). Eckwerte für ein mögliches flexibles Wasserzinsmaximum - Bericht zuhanden der UREK-N. Eidgenössisches Departement für Umwelt, Verkehr, Energie und Kommunikation UVEK.

Swiss Federal Office of Energy, SFOE. (2018b). Revision StromVG Ausgestaltung einer Speicherreserve. Faktenblatt Version 2.0 vom 17. Oktober 2018.

\section{Publisher's Note}

Springer Nature remains neutral with regard to jurisdictional claims in published maps and institutional affiliations.

\section{Submit your manuscript to a SpringerOpen ${ }^{\circ}$ journal and benefit from:}

- Convenient online submission

- Rigorous peer review

- Open access: articles freely available online

- High visibility within the field

- Retaining the copyright to your article

Submit your next manuscript at $>$ springeropen.com 